\title{
The effects of caloric restriction and age on thyroid hormone signalling in the heart of rats
}

\author{
K. Lachowicz ${ }^{1,3}$, E. Fürstenberg', E. Pałkowska1', M. Stachoń1, D. Gajewska1', J. Myszkowska-Ryciak', \\ L. Kozłowska ${ }^{1}$, A. Ciecierska ${ }^{2}$ and D. Rosołowska-Huszcz ${ }^{1}$ \\ Warsaw University of Life Sciences, SGGW, ${ }^{1}$ Department of Dietetics, Faculty of Human Nutrition and Consumer Sciences \\ ${ }^{2}$ Department of Physiological Sciences, Faculty of Veterinary Medicine \\ Nowoursynowska 159c, 02-776 Warsaw, Poland
}

KEYWORDS: energy deficit, thyroid hormones, TSH, thyroid hormone receptors, deiodinases, cardiac myosin heavy chains, rat

Received: 7 November 2013

Revised: 14 January 2014

Accepted: 4 March 2014

${ }^{3}$ Corresponding author:

e-mail: katarzyna_lachowicz@sggw.pl
ABSTRACT. Thyroid hormones (TH) are believed to participate in adaptation of the heart to dietary caloric restriction (CR). The effect of CR on cardiac thyroid hormone receptors $\alpha$ and $\beta$ (TRa and TR $\beta$ ) has been hitherto insufficiently investigated, however, and with respect to the impact of CR on cardiac type 2 and 3 deiodinases (D2 and D3), we have not found any literature data. The aim of this study was to assess the effect of $\mathrm{CR}$ and age on thyroid hormone (TH) signalling (D2, D3, TR $\alpha$ and $\beta$ ) and myosin heavy chain $\beta$ (BMHC) in the heart. The study was performed on 17-week- and 45-week-old male Sprague Dawley rats, fed ad libitum (AL) or restricted to $80 \%$ or $60 \%$ of $A L$ energy intake. Plasma concentrations of TSH, total and free T3 and T4 (fT3 and $\mathrm{TT} 4$ ), protein levels of heart D2 and D3, THRa, THR $\beta$, myosin heavy chain $\beta$ (BMHC) mRNA expression and cardiac BMHC protein were determined. Morphological and endocrine parameters were influenced by age (fT3/T3, fT4/T4, THRa, BMHC protein), feeding level (TSH, T4, T3, BMHC mRNA), or by both age and feeding level (body weight, fT4, fT3). Caloric restriction reduced fT3, T4, and fT4 levels in both age groups, with additional decreases in TSH and T3 occurring in younger rats. Independently of age, cardiac BMHC expression was positively correlated with cardiac D3 and negatively with food intake and thyroid hormones. The most important finding of our study is that cardiac D3 and BMHC protein are, under conditions of differentiated dietary energy supply, directly related in both young and middle-aged rats.

\section{Introduction}

Thyroid hormone homeostasis plays an important role in the control of normal cardiac function. The heart is one of the organs sensitive to variations in circulating TH levels, and thyroid dysfunction is associated with changes in myocardial contractility and its failure (Schmidt-Ott and Ascheim, 2006).
Genomic effects of TH are mediated by their binding to $\alpha$ and $\beta$ nuclear thyroid hormone receptors that regulate transcriptional activation or repression of various cardiomyocyte genes (Kahally and Dilmann, 2005). Myosin heavy chains $\alpha$ (AMHC) and $\beta$ (BMHC) are among proteins whose expression is modulated by TH. BMHC have lower ATPase activity and slower contraction velocity and force than 
AMHC (Hirzel et al., 1985). BMHC expression is induced by pathological cardiac hypertrophy (Pandya and Smithies, 2011), hypoxia (Razeghi et al., 2003) and caloric restriction (Swoap et al., 1995). Thyroid hormones positively regulate AMHC, while they repress expression of BMHC (Pachucki et al., 2001; Weltman et al., 2013).

The main secretory product of the thyroid gland is $3,3,5,5^{\prime}$ tetraiodothyronine (T4), which is deiodinated in target tissues by selenoenzymes - iodothyronine deiodinases. In the heart, triiodothyronine (T3) is produced through outer ring deiodination of T4 catalysed by type 2 iodothyronine deiodinase (D2) localized in the myocardium in humans, and in non-myocardium cells of the heart in rodents (Biondi and Klein, 2004). When type 3 deiodinase (D3) deiodinates the inner ring of $\mathrm{T} 4$, it creates inactive reverse triiodothyronine (rT3) (Pantos et al., 2011). Type 3 deiodinase is expressed in many tissues during foetal life. Postnatally, D3 expression disappears and in adult life it is observed in some tissues only, including brain, skin and the pregnant uterus (Dentice and Salvatore, 2011). Reexpression of D3 has been observed in diverse models of tissue injuries, however (Huang and Bianco, 2008). In the heart, reexpression of $\mathrm{D} 3$ has been observed in pathophysiological conditions like myocardial infarction, cardiac hypertrophy and failure, and it is considered to be responsible for the local hypothyroid state occurring in heart failure (Dentice and Salvatore, 2011).

Thyroidal axis activity is down-regulated by food restriction (Heilbronn and Ravussin, 2003; Redman and Ravussin, 2009; Araujo and Carvalho, 2011). Under food restriction, pituitary responsiveness to TRH is generally depressed and the serum TSH concentration decreases in rats (Araujo and Carvalho, 2011). In addition, a decrease in plasma T3 (Fontana et al., 2006) and/or T4 (Gromakova and Konovalenko, 2004) and an increase in rT3 levels are observed (Darras et al., 1995). With respect to peripheral metabolism of TH, fasting has been demonstrated to decrease D2 activity in the liver (Gyorffy et al., 2009), increase D3 activity in this organ (Van der Geyten et al., 1999; Boelen et al., 2012), and to decrease D3 in the kidneys (Van der Geyten et al., 1999).

Caloric restriction is believed to reduce cardiovascular risk factors and slow down heart aging via reduction of mitochondrial reactive oxygen species in plasma and heart tissues (Minamiyama et al., 2007; Shinmura et al., 2011). On the other hand, several CR effects leading to alterations in gene expression and protein profile and deterioration of heart function have been reported (Katzeff et al., 1997;
Sugizaki et al., 2009, 2011; Yamagishi et al., 2010). To our knowledge, effects of caloric restriction on thyroid hormone deiodinases in the heart have not been investigated yet.

In this study, we aimed to assess the effects of $\mathrm{CR}$ and age on cardiac type 2 and 3 thyroid hormone deiodinases, thyroid hormone receptors $\alpha$ and $\beta$, and expression of myosin heavy chain isoform $\beta$. Additionally, we attempted to relate these effects to the impact of CR on thyroid axis hormones that are known, on the one hand, to respond to energy deficit and, on the other hand, to influence cardiac morphology.

\section{Material and methods}

\section{Study protocol}

Forty-two normal male Sprague-Dawley rats (Mossakowski Medical Research Centre animal house, Warsaw, Poland) forming two age groups were used. At the beginning of the experiment, following a two-week adaptation period, the younger rats were 17 weeks old (body weight, BW, 442.2 \pm $35.3 \mathrm{~g}$ ) and the older rats were 45 weeks old (BW $594.4 \pm 42.3 \mathrm{~g}$ ). The younger and older rats were divided into three groups of seven. The first group was fed ad libitum (AL) on a standard diet. The second and the third groups were subjected to $\mathrm{CR}$. The AL animals had unlimited access to a stock rat diet (Table 1). Feed intakes of CR rats were updated weekly to $80 \%$ (20\% deficit, CR20) and 60\% (40\% deficit, CR40) energy intakes of AL rats. The energetic value of CR rations was obtained by reducing the content of carbohydrates and fat. CR diets were supplemented with protein (casein) and a mineral-vitamin mixture to the AL ingredient intake (Table 1). Feed consumption of all groups was measured every day and the animals were weighed weekly. Animals had free access to water. Housing conditions included individual cages, 12-h light/dark cycle, temperature $22^{\circ} \mathrm{C}$, and relative humidity $60 \%$. The study protocol was approved by the Local Animal Care and Use

Table 1. Composition of experimental diets

\begin{tabular}{llrl}
\hline Components, & Diets & & \\
\cline { 2 - 4 } $\mathrm{g} \cdot 100 \mathrm{~g}^{-1}$ diet & $\mathrm{AL}^{\mathrm{a}}$ & $\mathrm{CR} 20^{\mathrm{b}}$ & \multicolumn{1}{c}{$\mathrm{CR}^{\circ} 0^{\mathrm{c}}$} \\
\hline Protein & 21.20 & 26.40 & 35.00 \\
Carbohydrates & 70.60 & 65.70 & 57.50 \\
Fat & 3.80 & 3.50 & 3.10 \\
\hline
\end{tabular}

a SSNIFF diet ( V1320-000, SSNIFF Spezialdiäten GmbH, Germany); ${ }^{b}$ average composition of nine modified SSNIFF diets with $20 \%$ energy deficit (supplemented with protein and mineral-vitamin mixture, R122F002, SSNIFF Spezialdiäten GmbH);

caverage composition of nine modified SSNIFF diets with $40 \%$ energy deficit (supplemented with protein and mineral-vitamin mixture, R122F002, SSNIFF Spezialdiäten GmbH) 
Committee (Warsaw University of Life Sciences, SGGW, Poland).

At the end of the nine-week experiment the rats were fasted overnight and an aesthetised by isoflurane. Blood was collected from the heart into EDTA-ised tubes, centrifuged at $2300 \mathrm{~g}$ and $4^{\circ} \mathrm{C}$ for $15 \mathrm{~min}$. Pending analysis, plasma was stored at $-23^{\circ} \mathrm{C}$. Hearts were excised, specimens of the heart tissue were collected, snap immersed in RNAlater, and stored for mRNA determination. Next, the hearts were immediately frozen in liquid nitrogen. All samples were stored at $-80^{\circ} \mathrm{C}$ until molecular and cellular analyses.

\section{Pituitary-thyroid axis hormone and cardiac protein levels}

Plasma TSH, T4, fT4, T3 and fT3 concentrations were determined by RIA kits (Izotop, Institute of Isotopes Co., Ltd., Hungary). The sensitivities of tests were $0.5 \mathrm{ng} \cdot \mathrm{ml}^{-1}, 7 \mathrm{nmol} \cdot 1^{-1}, 0.7 \mathrm{pmol}$. $1^{-1}, 0.3 \mathrm{nmol} \cdot 1^{-1}$, and $0.58 \mathrm{pmol} \cdot 1^{-1}$, respectively. Intraassay coefficients of variance (InaCV) were $4.8 \%, 3.94 \%, 2.61 \%, 5.44 \%$ and $4.46 \%$, respectively. Interassay coefficients of variance (IneCV) amounted to $13.2 \%, 3.82 \%, 5.67 \%, 5.48 \%$ and $7.76 \%$, respectively. Plasma rT3 was measured by an RIA test (ZenTech S.A., Belgium). The sensitivity of the test was $0.009 \mathrm{ng} \cdot \mathrm{ml}^{-1}$, InaCV was $6.49 \%$ and IneCV of $7.60 \%$.

ELISA kits (Uscn Life Science Inc., China) were used to estimate cardiac D2, D3, THR $\alpha$, THR $\beta$ and BMHC protein levels. The sensitivities of the tests were: less than $0.24 \mathrm{ng} \cdot \mathrm{ml}^{-1}, 0.117 \mathrm{ng} \cdot \mathrm{ml}^{-1}$, $0.268 \mathrm{ng} \cdot \mathrm{ml}^{-1}, 0.132 \mathrm{ng} \cdot \mathrm{ml}^{-1}$, and $43 \mathrm{pg} \cdot \mathrm{ml}^{-1}$, respectively.

Estimations of cardiac proteins were performed in the left cardiac ventricle. Heart tissues (weighing 0.9-1.6 g) were thoroughly rinsed in ice-cold PBS $\left(0.02 \mathrm{mmol} \cdot 1^{-1}, \mathrm{pH} 7.2\right)$ and homogenized in $5 \mathrm{ml}$ of PBS by an electric homogenizer $(7 \times 95 \mathrm{~mm}$ generator, PRO Scientific Inc., Oxford, UK) on ice. The resulting suspensions were subjected to two freezethaw cycles and homogenates were centrifuged at $5000 \mathrm{~g}$ for $5 \mathrm{~min}$. Supernatants were aliquoted and stored at $-80^{\circ} \mathrm{C}$ for further analyses. Levels of heart markers were expressed per milligram heart homogenate protein (for D2, D3, THR $\alpha$ and THR $\beta$ : $\mathrm{ng} \cdot \mathrm{mg}^{-1}$ protein and for BMHC: $\mathrm{pg} \cdot \mathrm{mg}^{-1}$ protein) as determined by the microtitred Bradford method (1.10306. BIOQUANT, MERCK, Germany) with bovine serum albumin as the standard (SIGMAALDRICH, USA).

\section{Real-time polymerase chain reaction}

Total RNA from heart samples was isolated using a total RNA kit (A\&A Biotechnology, Poland). RNA quantity was measured with the use of NanoDrop (NanoDrop Technologies, USA). Samples with adequate amounts of RNA were treated with TURBO DNAse (Applied Biosystems, USA) and the samples were again analysed with a BioAnalyzer (Agilent, USA) to measure final RNA quality and integrity. Total RNA $(0.1 \mu \mathrm{g})$ was reverse-transcribed using High Capacity RNA-to-cDNA Master Mix (Applied Biosystems, USA). Expression of genes was analysed by RT TaqMan PCR, TaqManUnivesal PCR Master Mix (Applied Biosystems, USA). Each reaction mixture contained $0.1 \mu \mathrm{g}$ of cDNA and the VIC-labelled TaqMan probe (Rn00568328 m1) designed by Applied Biosystems, USA). Additionally, three endogenous controls were used: Rat GAPDH, VIC-labelled; Rat ACTB, FAM-labelled and Rat Ubc, FAM-labelled (Applied Biosystems, USA). TaqMan PCR was performed using a Stratagene Mx3005P QPCR System (Agilent Technologies, USA) with initial incubation at $50^{\circ}$ for $2 \mathrm{~min}$, a denaturation step at $95^{\circ}$ for $10 \mathrm{~min}$, then $40 \mathrm{cy}-$ cles of denaturation at $95^{\circ}$ for $15 \mathrm{~s}$, and an annealing/extension step at $60^{\circ}$ for $1 \mathrm{~min}$. The emission was measured at the annealing-extension step. For each PCR reaction, the cycle threshold $(\mathrm{Ct})$ value, i.e. the number of PCR cycles necessary to increase fluorescence above background, was automatically calculated and analysed by MxPro QPCR Software (version 4.10, Agilent Technologies, USA).

\section{Statistical analyses}

Values are presented as means (SE) or median (min-max). Results obtained were subjected to data distribution (Shapiro-Wilk test) and variance homogeneity (Bartlett test) tests. Homogenous and normally distributed data were analysed for differences between groups by means of two-way analysis of variance (ANOVA) and by Tukey's test for posthoc analysis. Data coming from normal distribution were log-transformed and analysed by employing ANOVA and the above-mentioned tests. In parallel, Kruskal-Wallis ANOVA, U Mann-Whitney nonparametric tests were used to analyse abnormally distributed data. Correlations between concerned variables were assessed by means of the Pearson correlation method or the Spearman test. Statistical significance was accepted for $P$ values at a level less than 0.05 . All statistical analyses were performed using the Statistica v. 10 software package (StatSoft, USA). 
Table 2. Effects of caloric restriction and age on changes in body weight, feed efficiency, pituitary-thyroid axis hormones and cardiac parameters

\begin{tabular}{|c|c|c|c|c|c|c|}
\hline \multirow{2}{*}{ Parameters } & \multicolumn{3}{|l|}{ Younger rats } & \multicolumn{3}{|l|}{ Older rats } \\
\hline & $\mathrm{AL}^{\mathrm{c}}(\mathrm{n}=7)$ & $\mathrm{CR} 20^{\mathrm{d}}(\mathrm{n}=7)$ & $\mathrm{CR} 40^{\mathrm{e}}(\mathrm{n}=7)$ & $\mathrm{AL}^{\mathrm{c}}(\mathrm{n}=7)$ & $\mathrm{CR} 20^{\mathrm{d}}(\mathrm{n}=7)$ & $\mathrm{CR} 40^{\mathrm{e}}(\mathrm{n}=7)$ \\
\hline $\begin{array}{l}\text { Changes in body weight, } \\
\% \text { initial value }\end{array}$ & $110.15(1.53)$ & $94.13(1.94)^{*}$ & $84.05(2,51)^{\star} \dagger$ & $98.64(0.57) \ddagger$ & $90.87(1.36)^{*}$ & $76.50(2.1)^{*} \dagger \ddagger$ \\
\hline Feed efficiency ${ }^{b}$ & $\begin{array}{l}0.036 \\
(-0.077-0.060)\end{array}$ & $\begin{array}{l}-0.036^{*} \\
(-0.050-0.013)\end{array}$ & $\begin{array}{l}-0.079^{*} \dagger \\
(-0.166--0.050)\end{array}$ & $\begin{array}{l}-0.007 \\
(-0.014--0.0004)\end{array}$ & $\begin{array}{l}-0.047^{*} \\
(-0.098--0.022)\end{array}$ & $\begin{array}{l}-0.184 \dagger \ddagger \\
(-0.239--0.099)\end{array}$ \\
\hline $\mathrm{TSH}, \mathrm{ng} \cdot \mathrm{ml}^{-1 \mathrm{a}}$ & $17,29(2.88)$ & $9,25(1.03)^{*}$ & $7.72(0.57)^{*}$ & $10.96(0.98)$ & $10.71(1.12)$ & $8.56(0.72)$ \\
\hline $\mathrm{T} 4, \mathrm{nmol} \cdot \mathrm{I}^{-1 \mathrm{a}}$ & $67,19(1.56)$ & $56.86(4.30)$ & $54.95(2.83)^{*}$ & $60.93(2.27)$ & $58.35(3.86)$ & $50.77(2.22)^{*}$ \\
\hline $\mathrm{fT} 4, \mathrm{pmol} \cdot \mathrm{I}^{-1 \mathrm{~b}}$ & $\begin{array}{l}26.98 \\
(24.56-30.71)\end{array}$ & $\begin{array}{l}23.75 \\
(17.21-24.76)^{*}\end{array}$ & $\begin{array}{l}22.94 \\
(18.03-24.23)^{*}\end{array}$ & $\begin{array}{l}22.36 \\
(15.30-23.44) \ddagger\end{array}$ & $\begin{array}{l}20.37 \\
(17.02-23.87)\end{array}$ & $\begin{array}{l}16.74 \\
(14.60-21.59) \dagger \ddagger\end{array}$ \\
\hline $\mathrm{fT} 4 / \mathrm{T} 4^{\mathrm{a}}$ & $0.40(0.001)$ & $0.40(0.021)$ & $0.40(0.019)$ & $0.35(0.019) \ddagger$ & $0.36(0.020) \ddagger$ & $0.35(0.019) \ddagger$ \\
\hline $\mathrm{T} 3,\left.\mathrm{nmol} \cdot\right|^{-1 \mathrm{~b}}$ & $\begin{array}{l}1.50 \\
(1.38-1.61)\end{array}$ & $\begin{array}{l}1.12 \\
(0.96-1.47)^{*}\end{array}$ & $\begin{array}{l}1.05 \\
(0.87-1.16)^{*}\end{array}$ & $\begin{array}{l}1.45 \\
(1.34-1.81)\end{array}$ & $\begin{array}{l}1.10 \\
(0.90-2.68)\end{array}$ & $\begin{array}{l}1.19 \\
(0.97-2.04)\end{array}$ \\
\hline $\mathrm{fT} 3,\left.\mathrm{pmol} \cdot\right|^{-1 b}$ & $\begin{array}{l}3.44 \\
(2.68-3.59)\end{array}$ & $\begin{array}{l}2.83 \\
(2.13-3.63)\end{array}$ & $\begin{array}{l}2.17 \\
(1.89-4.07)^{*}\end{array}$ & $\begin{array}{l}2.79 \\
(1.76-3.25) \ddagger\end{array}$ & $\begin{array}{l}2.54 \\
(1.90-4.20)\end{array}$ & $\begin{array}{l}1.96 \\
(1.76-2.60)^{*} \dagger\end{array}$ \\
\hline $\mathrm{fT} 3 / \mathrm{T}^{\mathrm{a}}$ & $2,21(0.08)$ & $2.27(0.12)$ & $2.33(0.21)$ & $1.81(0.18)$ & $2.17(0.26)$ & $1.64(0.14) \ddagger$ \\
\hline $\mathrm{rT3}, \mathrm{nmol} \cdot \mathrm{I}^{-1 \mathrm{a}}$ & $0.15(0.015)$ & $0.15(0.018)$ & $0.12(0.015)$ & $0.13(0.015)$ & $0.13(0.011)$ & $0.13(0.001)$ \\
\hline THRa, ng $\cdot \mathrm{mg}^{-1}$ protein $^{b}$ & $\begin{array}{l}2.62 \\
(1.29-2.87)\end{array}$ & $\begin{array}{l}2.16 \\
(1.13-5.68)\end{array}$ & $\begin{array}{l}2.09 \\
(1.49-3.68)\end{array}$ & $\begin{array}{l}3.54 \\
(3.01-5.31) \ddagger\end{array}$ & $\begin{array}{l}3.07 \\
(2.08-4.21)\end{array}$ & $\begin{array}{l}3.70 \\
(2.96-5.25) \dagger \ddagger\end{array}$ \\
\hline THR $\beta$, ng $\cdot \mathrm{mg}^{-1}$ protein $^{\mathrm{a}}$ & $0.48(0.08)$ & $0.57(0.09)$ & $0.53(0.06)$ & $0.59(0.09)$ & $0.62(0.05)$ & $0.66(0.08)$ \\
\hline THRa/ THRßa & $6.01(1.40)$ & $5.08(0.88)$ & $5.01(0.91)$ & $7.28(1.11)$ & $5.18(0.60)$ & $6.65(0.97)$ \\
\hline $\mathrm{D} 2, \mathrm{ng} \cdot \mathrm{mg}^{-1}$ protein $^{\mathrm{a}}$ & $3.52(0.60)$ & $4.87(1.13)$ & $3.90(0.54)$ & $4.26(0.61)$ & $3.91(0.59)$ & $4.32(0.51)$ \\
\hline $\mathrm{D} 3, \mathrm{ng} \cdot \mathrm{mg}^{-1}$ protein $^{\mathrm{a}}$ & $0.031(0.004)$ & $0.041(0.010)$ & $0.052(0.015)$ & $0.042(0.004)$ & $0.049(0.011)$ & $0.058(0.012)$ \\
\hline $\mathrm{BMHC}$ mRNA $(\mathrm{Cp})^{\mathrm{a}}$ & $19.39(1.20)$ & $32.92(6.65)$ & $35.27(2.09)^{\star}$ & $18.33(3.06)$ & $30.30(4.31)^{\star}$ & $49.37(8.74)^{*}$ \\
\hline BMHC, ng $\cdot \mathrm{mg}^{-1}$ protein $^{\mathrm{a}}$ & $284.96(17.38)$ & $241.60(24.00)$ & $278.14(42.94)$ & $317.80(29.81)$ & $342.09(22.42)$ & $432.86(40.93) \ddagger$ \\
\hline
\end{tabular}

${ }^{a}$ values are expressed as mean (SE), ${ }^{b}$ values are expressed as median (min-max), ${ }^{\circ} \mathrm{AL}-$ fed ad libitum, ${ }^{\mathrm{d}} \mathrm{CR} 20-80 \%$ of energy intake of $A L,{ }^{e} \mathrm{C} R 40-60 \%$ of energy intake of $\mathrm{AL}$, compared with corresponding AL groups ${ }^{*} P<.05$; compared with corresponding CR20 groups, $\dagger P \leq 05$; compared with corresponding younger group, $\ddagger P<.05$ ('ANOVApost hoc Tuckey test, ${ }^{b} \mathrm{U}$ Mann-Whitney test)

\section{Results}

\section{Changes in body weight and feed efficiency}

Changes in BW expressed as a percentage of the initial value are presented in Table 2. Both age and energy restriction affected BW significantly, with BW gain being higher in the younger than in the older group $(P<0.00003)$. Generally a higher energy deficit the lower BW gain was observed $(P<0.0000001)$. Feed growth efficiency was higher in younger rats $(P<0.00001)$.

\section{Pituitary-thyroid axis hormone levels}

Plasma TSH and total T4 concentrations were affected by the feeding level $(P<0.003$ and $P<0.006$, respectively) only. Plasma fT4 concentrations were influenced by both age and feeding $(P<0.0003$ and $P<0.005$, respectively). The ratio between fT 4 and T4 (fT4/T4) depended on age, with fT4/T4 higher in younger vs older rats $(P<0.008)$, but not on the feeding level (Table 2).

Plasma total T3 concentrations were affected only by the feeding level $(P<0.00001)$. Plasma fT3 was influenced by age as well as by the feeding level $(P<0.04$ and $P<0.002$, respectively) (Table 2$)$.
Plasma levels of rT3 remained unaffected by both the diet and age (Table 2).

Correlations between energy intakes and thyroid parameters are summarised in Table 3.

Table 3. Correlations between energy intakes and selected thyroid parameters

\begin{tabular}{llllll}
\hline \multirow{2}{*}{ Parameters } & \multicolumn{2}{l}{ Younger rats } & & \multicolumn{2}{l}{ Older rats } \\
\cline { 2 - 3 } & $R$ & $P<$ & & $P<$ \\
\hline TSH & 0.58 & 0.006 & & NS & \\
T4 & 0.54 & 0.02 & & 0.51 & 0.02 \\
fT4 & 0.75 & 0.0001 & & 0.55 & 0.009 \\
T3 & 0.85 & 0.0001 & & NS & \\
fT3 & 0.63 & 0.002 & 0.58 & 0.005 \\
\hline
\end{tabular}

\section{Cardiac THR $\alpha$ and THR $\beta$ protein levels}

Cardiac THR $\alpha$ levels depended on age $(P<0.0003)$ (Table 2). Caloric restriction did not significantly affect THR $\alpha$. In turn, THR $\beta$ levels as well as cardiac THR $\alpha /$ THR $\beta$ were not dependent on any experimental parameters, as depicted in Table 2. In younger rats, THR $\alpha$ correlated positively with fT4/ T4 $(R=0.57 ; P<0.02)$. In older rats, a negative correlation between THR $\beta$ and rT3 plasma concentrations was found $(R=-0.47 ; P<0.03)$. 


\section{Cardiac D2 and D3 protein levels}

Cardiac D2 and D3 proteins were not influenced by either age or diet (Table 2). In younger rats, D3 protein correlated positively with THR $\alpha$ (Figure 1).

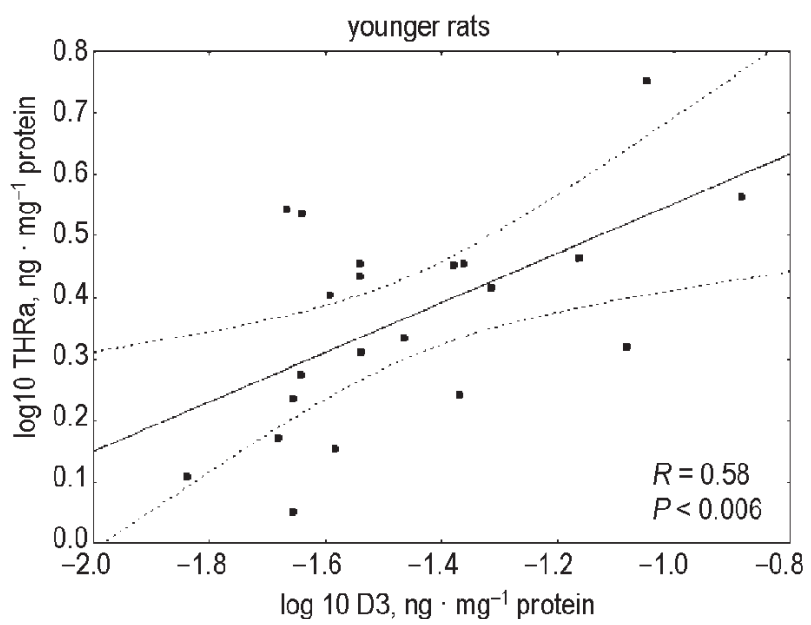

Figure 1. Correlation between thyroid hormone receptors a (THRa) and type 3 iodothyronine deiodinase (D3) protein levels in younger rats

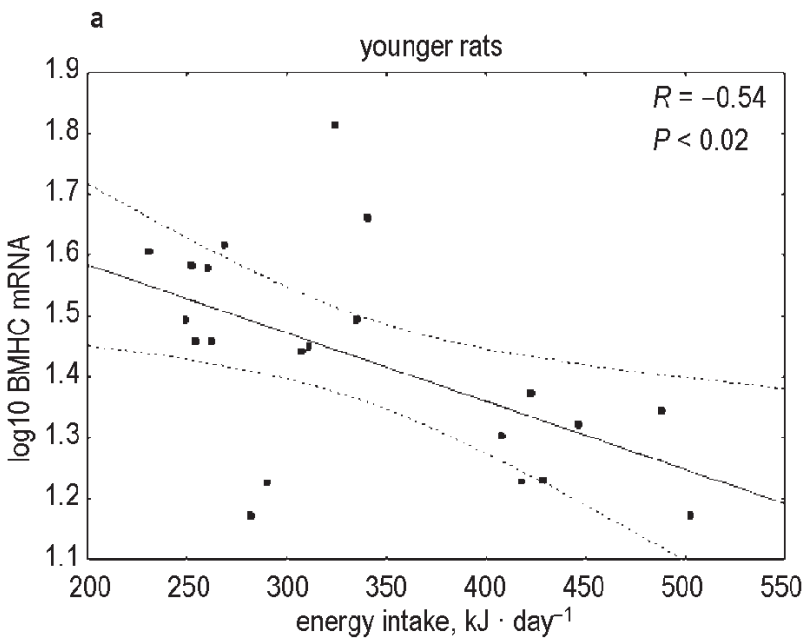

\section{Cardiac BMHC mRNA and protein levels}

Cardiac BMHC mRNA was influenced by energy restriction $(P<0.00001)$, but not by age. Energy restriction at both levels augmented BMHC mRNA expression (Table 2).

BMHC protein did not differ in AL groups and the effect of $\mathrm{CR}$ on BMHC protein was significant only in older CR40 rats (effect of age, $P<0.00031$ ) (Table 2).

In younger and older rats, BMHC mRNA was inversely related to feed intake (Figures $2 \mathrm{~A}$ and 2B), and to thyroid hormones: in younger rats negatively to T4 $(R=-0.53 ; P<0.02)$, in older animals, negatively to T4 $(R=-0.49 ; P<0.03)$, fT4 $(\mathrm{R}=-0.60 ; P<0.003)$ and the fT3/T3 ratio $(R=-0.44 ; P<0.04)$. In both age groups, the $\mathrm{BMHC}$ protein level was directly related to the D3 protein level (Figures 3A and 3B).

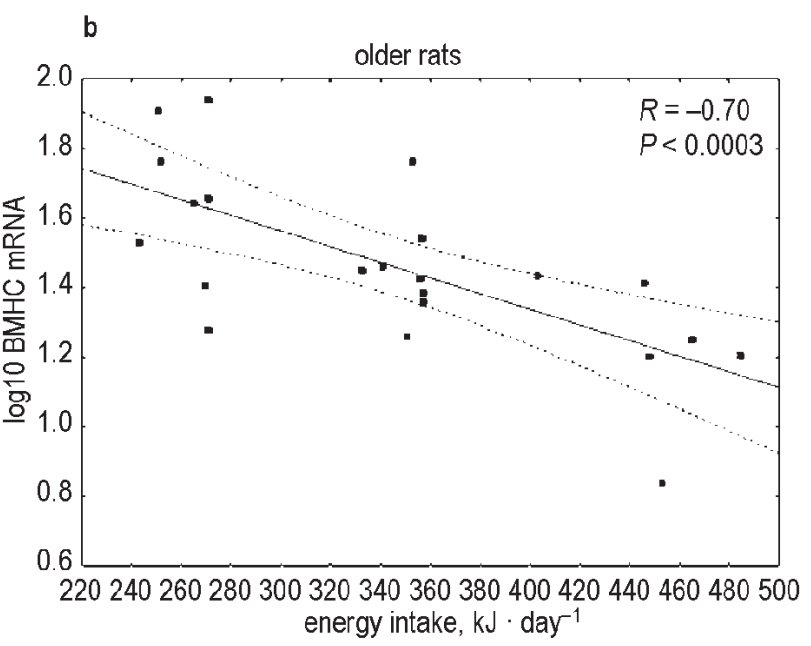

Figure 2. Correlations between $\beta$ myosin heavy chain (BMHC) mRNA in the heart and feed intakes: $(A)$ in younger and $(B)$ older rats
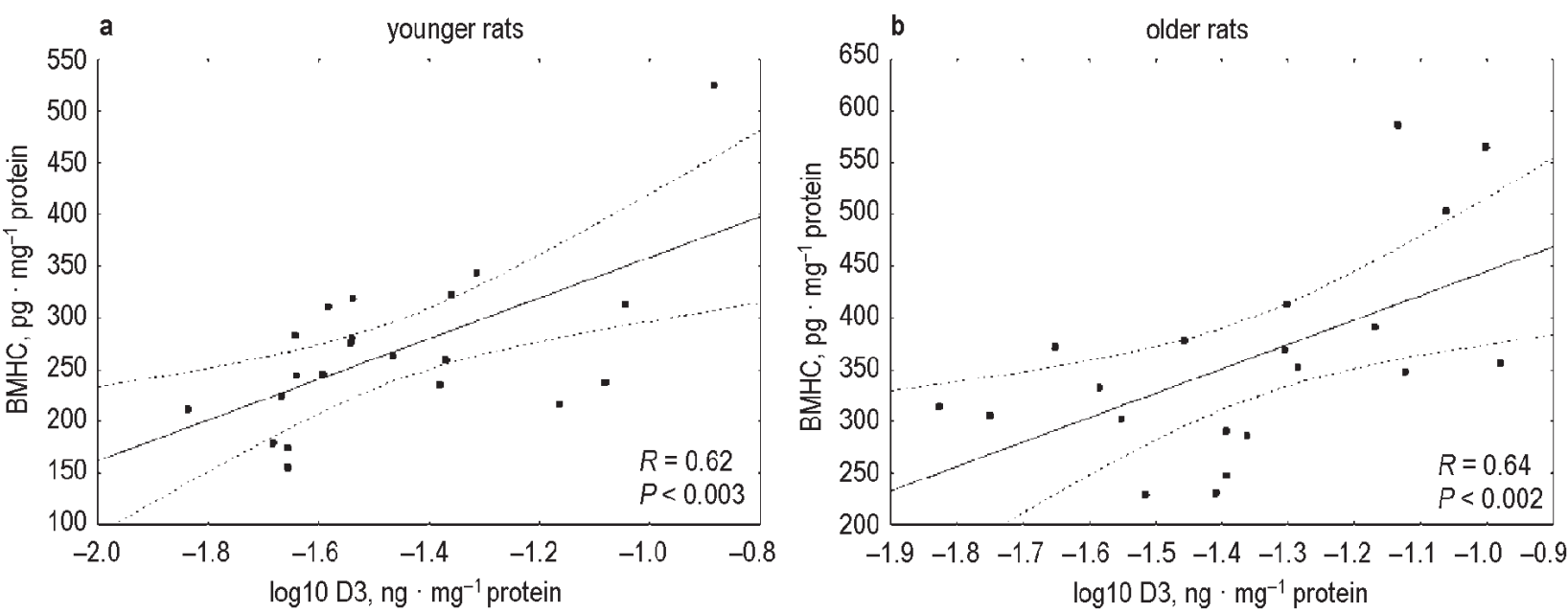

Figure 3. Correlation between BMHC and type 3 deiodinase (D3) protein levels in the heart: $(A)$ in younger and (B) older rats 


\section{Discussion}

In our study, caloric restriction evoked changes in pituitary-thyroid axis activity and cardiac myosin heavy chain $\beta$ isoform expression.

Decreases in thyroid axis activity induced by fasting and dietary restriction have been observed in both humans (Redman and Ravussin, 2009) and rats (Araujo et al., 2009). As in other studies, in our experiment, CR caused alterations in plasma concentrations of pituitary thyroid axis hormones despite adequate protein, vitamin and mineral intakes. A more expressed response of pituitary thyroid axis to $\mathrm{CR}$ in younger rats, as well as stronger correlations between feed intakes and hormone concentrations, may indicate age-associated changes in the adaptation to caloric restriction. The age-related declines in T3 and T4 free fractions may result from an increase in thyroid hormone binding globulin expression observed during aging, as shown by Savu et al. (1991). The effect of CR on thyroid hormones could be strain-dependent, since, unlike in our study conducted in male Sprague Dawley rats, a decline in total T4 was observed in 12-month-old Wistar rats as compared with their 6-month-old counterparts (Silvestri et al., 2008).

Despite changes in TH plasma concentrations, we did not show any significant effect of CR on cardiac THR levels. Thyroid hormone treatment has been reported to increase cardiac THR $\alpha 1$ levels, and TH deprivation evoked an opposite effect (Sadow et al., 2003). In another study, decreased expression of THR $\alpha$ has been observed in Wistar Kyoto rats subjected to $50 \%$ feed restriction for a period twice longer than in our experiment. In contrast to our study, however, the animals received $50 \%$ of the feed ingested by the control group without replenishment of protein, minerals and vitamins to the $a d$ libitum intakes (Sugizaki et al., 2009). Thus, in our experiment the undifferentiated intakes of protein, minerals, and vitamins could have resulted in the lack of difference in THR $\alpha$ between ad libitum fed and caloric restricted rats. In older rats, a negative correlation between THR $\beta$ and rT3 plasma concentration was found. The plasma rT3 level reflects the intensity of 5 deiodination. Since a rise in 5 deiodination could be connected with a drop in 5'deiodination, this relationship might indicate a reduction in THR $\beta$. This fall could result from a diminution of the T3 level, because THR $\beta$ expression is stimulated by T3 (Kinugawa et al., 2001; Liu et al., 2007).

To our knowledge, cardiac thyroid hormone receptors during aging have been poorly investigated as yet. In a study conducted on Wistar rats, cardiac
THR $\alpha 1$ declined between 2 and 6 months of age, and THR $\beta$ between 6 and 24 months of age (Long et al., 1999). Our results are not in conflict with these observations. We compared 26- week- and 54-weekold rats and did find higher THR $\alpha$ levels in older animals, whereas THR $\beta$ levels were not affected by age. The higher THR $\alpha$ in older rats could reflect compensation for age-related decreases in fT3 and fT4 plasma levels.

Caloric restriction induced an increase in BMHC mRNA expression in both age groups. Moreover, despite an increase in BMHC mRNA, we did not observe significant changes in BMHC protein evoked by $\mathrm{CR}$ in the younger group, although in older rats such an effect appeared. Alterations in cardiac proteins regulated by $\mathrm{TH}$ - increases in $\mathrm{BMHC}, \mathrm{Ca}$ channels, phospholamban, as well as a decrease in response to feed and caloric restriction are also reported by other investigators (Swoap et al., 1995; Katzeff et al., 1997; Sugizaki et al., 2009, 2011; Yamagishi et al., 2010). Nonetheless, we did not find examples in the literature of statistically significant correlations between feed consumption or thyroid hormone levels and BMHC mRNA expression.

We observed that age had an impact on BMHC protein in CR rats only, while in AL rats, BMHC protein did not differ between both age groups. In other studies comparing BMHC\% in Fisher 344 x Brown Norway F1 hybrid rats, BMHC\% increased gradually from 3 to 9,21 and 33 months of age (Fitzsimons et al., 1999), and was higher as well in 10-month-old Sprague Dawley rats than in 5-month-old ones (Carnes et al., 2004). The difference between our results and others might be due to estimation of absolute, not relative, BMHC protein levels, which depends on the amount of isoform $\alpha$ myosin heavy chain.

Both type 2 and type 3 deiodinases were not significantly affected by experimental conditions as assessed by multifactorial analysis of variance. Type 2 deiodinase expression in rodent heart is much lower than in human heart (Croteau et at., 1996), therefore rodents are not considered a suitable model for human D2 regulation. Cardiac D2 mRNA and activity in mouse and rats has, however, been demonstrated to respond to changes in thyroid hormone levels induced by hypothyroidism provoked by methimazol treatment (Wagner et al., 2003) or iodine deficiency (Lavado-Autric et al., 2013) and attenuated by T3 administration (Wagner et al., 2003). This could indicate that in our study, local changes in thyroid hormone evoked by CR were not sufficient to alter D2 expression.

To our knowledge, we are the first to have observed a direct relationship between heart D3 and 
BMHC in both age groups. Thus, we suppose that cardiac D3 could be involved in a local decrease in $\mathrm{T} 3$ due to a rise in $\mathrm{T} 4$ ring deiodination. This could unblock BMHC gene expression during caloric restriction. Moreover, cardiac D3 expression has been reported to be induced by hypoxia inducible factor $1 \alpha($ HIF $1 \alpha)$.This leads to a decrease in T3-dependent oxygen consumption (Simonides et al., 2008). During CR, hypoxic conditions could result from atrophy of cardiac capillaries delivering oxygen. Such an effect was already observed after 7 days of $50 \%$ caloric restricted feeding of mice (Gruber et al., 2012). Cardiomyocyte hypoxia has also been observed in cardiac hypertrophy as cardiomyocyte diameter increased and oxygen diffusion deteriorated (Des Tombe et al., 2002). This would not be the case in our experiment, however, since caloric restriction has been shown to reduce cardiac hypertrophy (Ahmet et al., 2011). Recently, D3 expression has been observed both in vitro and in vivo to be stimulated by T3-liganded THR $\alpha$ in the brain and hypophysis, but not in the liver (Barca-Mayo et al., 2011). Although significant in younger rats only, the direct relationship found in our study between cardiac THR $\alpha$ and D3 enables us to hypothesize that THR $\alpha$ plays an essential role in the induction of D3 expression in the heart.

\section{Conclusions}

Caloric restricted feeding induced a decline in thyroid activity and an increase in cardiac myosin $\beta$ heavy chain isoform mRNA expression. The effect of age in response to caloric restriction was seen in the pituitary thyroid axis and myosin heavy chain $\beta$ (BMHC) protein. Although thyroid response was more expressed in younger rats, in contrast, older rats responded more strongly in respect to (BMHC) protein level. Cardiac deiodinase 3 (D3) might be engaged in the effect of caloric restriction on BMHC because of the direct relationship between their levels. Thus, the most important finding of our study is that under conditions of differentiated dietary energy supply, D3 and BMHC protein are directly related in both young and middle-aged rats.

\section{Acknowledgements}

This work was supported by the Ministry of Science and Higher Education of Poland, Grant No. N312 379037.

\section{References}

Ahmet I., Tae H.J., de Cabo R., Lakatta E.G., Talan M.I., 2011. Effects of caloric restriction on cardioprotection and cardiovascular health. J. Mol. Cell. Cardiol. 51, 263-271

Araujo R.L., Andrade B.M., da Silva M.L., Ferreira A.C., Carvalho D.P., 2009. Tissue-specific deiodinase regulation during food restriction and low replacement dose of leptin in rats. Amer. J. Physiol. - Endocrinol. Met. 296, E1157-E1163

Araujo R.L., Carvalho D.P., 2011. Bioenergetic impact of tissue-specific regulation of iodothyronine deiodinases during nutritional imbalance. J. Bioenerg. Biomembrane. 43, 59-65

Barca-Mayo O., Liao X.H., Alonso M., Di Cosmo C., Hernandez A., Refetoff S., Weiss R.E., 2011. Thyroid hormone receptor a and regulation of type 3 deiodinase. Mol. Endocrinol. 25, $575-583$

Biondi B., Klein I., 2004. Hypothyroidism as a risk factor for cardiovascular disease. Endocrine 24, 1-13

Boelen A., van Beeren M., Vos X., Surovtseva O., Belegri E., Saaltink D.J., Vreugdenhil E., Kalsbeek A., Kwakkel J., Fliers E., 2012. Leptin administration restores the fasting-induced increase of hepatic type 3 deiodinase expression in mice. Thyroid 22, 192-199

Carnes C.A., Geisbuhler T.P., Reiser P.J., 2004. Age-dependent changes in contraction and regional myocardial myosin heavy chain isoform expression in rats. J. Appl. Physiol. 97, 446-453

Croteau W., Davey J.C., Galton V.A., StGermain D.L., 1996. Cloning of the mammalian type II iodothyronine deiodinase. J. Clin. Invest. 98, 405-417

Darras V.M., Cokelaere M., Dewil E., Arnouts S., Decuypere E., Kühn E.R., 1995. Partial ford restriction increases hepatic inner ring deiodinating activity In the chicken and in the rat. Gen. Comp. Endocrinol. 100, 334-338

Dentice M., Salvatore D., 2011. Deiodinases: the balance of thyroid hormone: local impact of thyroid hormone inactivation. J. Endocrinol. 209, 273-282

Des Tombe A.L., Van Beek-Harmsen B.J., Lee-De Groot M.B., Van Der Laarse W.J., 2002. Calibrated histochemistry applied to oxygen supply and demand in hypertrophied rat myocardium. Microsc. Res. Technique 58, 412-420

Fitzsimons D.P., Patel J.R., Moss R.L., 1999. Aging-dependent depression in kinetics of force development in rats skinned myocardium. Amer. J. Physiol. - Heart Circ. Physiol. 276, H1511-H1519

Fontana L., Klein S., Holloszy J.O., Premachandra B.N., 2006. Effect of long-term caloric restriction with adequate protein and macronutrients on thyroid hormones. J. Clin. Endocrinol. Metab. 91, 3232-3235

Gromakova I.A., Konovalenko O.A., 2004. Effects of aging and lifeprolonging diet on thyroid regulation of protein synthesis. Bull. Exp. Biol. Med. 137, 276-279

Gruber C., Nink N., Nikam S., Magdowski G., Kripp G., Voswinckel R., Mühlfeld C., 2012. Myocardial remodeling in left ventricular atrophy induced by caloric restriction. J. Anat. 220, 179-185

Gyorffy A., Sayed-Ahmed A., Zsarnovszky A., Frenyó V.L., Decuypere E., Bartha T., 2009. Effects of energy restriction on thyroid hormone metabolism in chickens. Acta Vet. Hung. 57, 319-330

Heilbronn L.K., Ravussin E., 2003. Caloric restriction and aging: review of the literature and implications for studies in humans. Amer. J. Clin. Nutr. 78, 361-369

Hirzell H.O., Tuschmid C.R., Schneider J., Krayenbuehl, Schaub M.C., 1985. Relationship between myosin isoenzyme composition, hemodynamics, and myocardial structure in various forms of human cardiac hypertrophy. Circ. Res. 57, 729-740 
Huang S.A., Bianco A.C., 2008. Reawakened interest in type III iodothyronine deiodinase in critical illness and injury. Nat. Clin. Pract. 4, 148-155

Kahaly G.J., Dillmann W.H., 2005. Thyroid hormone action in the heart. Endocrine Rev. 26, 704-728

Katzeff H.L., Powell S.R., Ojamaa K., 1997. Alterations in cardiac contractility and gene expression during low-T3 syndrome: prevention with T3. Amer. J. Physiol. 273, E951-E956

Kinugawa K., Yonekura K., Ribeiro R.C.J., Eto Y., Aoyagi T., Baxter J.D., Camacho S.A., Bristow M.R., Long C.S., Simpson P.C., 2001. Regulation of thyroid hormone receptor isoforms in physiological and pathological cardiac hypertrophy. Circ. Res. $89,591-598$

Lavado-Autric B., Calvo R.M., de Mena R.M., de Escobar G.M., Obregon M.J., 2013. Deiodinase activities in thyroids and tissues of iodine deficient female rats. Endocrinology 154, 529-536

Liu C.R., Li L.Y., Shi F., Zang X.Y., Liu Y.M., Sun Y., Kan B.H., 2007. Effects of hyper- and hypothyroid on expression of thyroid hormone receptor mRNA in rat myocardium. J. Endocrinol. 195, 429-438

Long X., Boluyt M.O., O'Neill L., Zheng J.-S., Wu G., Nitta Y.K., Crow M.T., Lakatta E.G., 1999. Myocardial retinoid x receptor, thyroid hormone receptor, and myosin heavy chain gene expression in the rat during adult aging. J. Gerontol. A. Biol. Sci. Med. Sci. 54, B23-B27

Minamiyama Y., Bito Y., Takemura S., Kodai S., Mizuguchi S., Nishikawa Y., Suehiro S., Okada S., 2007. Caloric restriction improves cardiovascular risk factors via reduction of mitochondrial reactive oxygen species in type II diabetic rats. J. Pharmacol. Exp. Ther. 320, 535-543

Pachucki J., Hopkins J., Peeters R., Tu H., Carvalho S.D., Kalbah H., Abel E.D., Wondisford F.E., Ingwall J.S., Larsen P.R., 2001. Type 2 iodothyronine deiodinase transgene expression in the mouse heart causes cardiac-specific thyrotoxicosis. Endocrinology $142,13-20$

Pandya K., Smithies O., 2011. MyHC and cardiac hypertrophy. Size does matter. Circ. Res. 109, 609-610

Pantos C., Mourouzis I., Cokkinos D.V., 2011. New insights into the role of thyroid hormone in cardiac remodeling: time to reconsider? Heart Fail. Rev. 16, 79-96

Razeghi P., Essop M.F., Huss J.M., Abbasi S., Manga N., Taegtmeyer H., 2003. Hypoxia-induced switches of myosin heavy chain iso-gene expression in rat heart. Biochem. Biophys. Res. Commun. 303, 1024-1027

Redman L.M., Ravussin E., 2009. Endocrine alterations in response to caloric restriction in humans. Mol. Cell. Endocrinol. 299, 129-136

Sadow P.M., Chassande O., Koo E.K., Gauthier K., Samarut J., Xu J., O'Malley B.W., Weiss R.E., 2003. Regulation of expression of thyroid hormone receptor isoforms and coactivators in liver and heart by thyroid hormone. Mol. Cell. Endocrinol. 203, 65-75

Savu L., Vranckx R., Rouaze-Romet M., Maya M., Nunez E.A., Tréton J., Flink I.L., 1991.A senescence up-regulated protein: the rat thyroxine-binding globulin (TBG). Biochim. Biophys. Acta 1097, 19-22

Schmidt-Ott U.M., Ascheim D., 2006. Thyroid hormone and heart failure. Curr. Heart Failure Rep. 3, 114-119

Shinmura K., Tamaki K., Sano M., Murata M., Yamakawa H., Ishida H., Fukuda K., 2011. Impact of long term caloric restriction on cardiac senescence: Caloric restriction ameliorates cardiac diastolic dysfunction associated with aging. J. Mol. Cell. Cardiol. 50, 117-127

Silvestri E., Lombardi A., de Lange P., Schiavo L., Lanni A., Goglia F., Visser T.J., Moreno M., 2008.Age-related changes in renal and hepatic cellular mechanisms associated with variations in rat serum thyroid hormone levels. Amer. J. Physiol. Endocrinol. Metab. 294, E1160-E1168

Simonides W.S, Mulcahey M.A., Redout E.M. et al., 2008. Hypoxiainducible factor induces local thyroid hormone inactivation during hypoxic-ischemic disease in rats. J. Clin. Invest. 118, 975-983

Sugizaki M.M., Leopoldo A.S., Okoshi M.P. et al., 2009. Severe food restriction induces myocardial dysfunction related to SERCA2 activity. Can. J. Physiol. Pharmacol. 87, 666-673

Sugizaki M.M., Lima-Leopoldo A.P., Conde S.J., Campos D.S., Damato R., Leopoldo A.S., Nascimento A.F., Oliveira JúniorSde A., Cicogna A.C., 2011. Upregulation of mRNA myocardium calcium handling in rats submitted to exercise and food restriction. Arq. Bras. Cardiol. 97, 46-52

Swoap S.J., Haddad F., Bodell P., Baldwin K.M., 1995. Control of betamyosin heavy chain expression in systemic hypertension and caloric restriction in the rat heart. Amer. J. Physiol. 269, C1025-C1033

Van der Geyten S., Van Rompaey E., Sanders J.P., Visser T.J., 1999. Regulation of thyroid hormone metabolism during fasting and refeeding in chicken. Gen. Comp. Endocrinol. 116, 272-280

Wagner M.S., Morimoto R., Dora J.M., Benneman A., Pavan R., Maia A.L., 2003. Hypothyroidism induces type 2 iodothyronine deiodinase expression in mouse heart and testis. J. Mol. Endocrinol. 31, 541-560

Weltman N.Y., Ojamaa K., Savinova O.V., Chen Y.-F., Schlenker E.H., Zucchi R., Saba A., Colligiani D., Pol C.J., Gerdes A.M., 2013. Restoration of cardiac tissue thyroid hormone status in experimental hypothyroidism: a dose-response study in female rats. Endocrinology 154, 2542-2552

Yamagishi T., Bessho M., Yanagida S., Nishizawa K., Kusuhara M., Ohsuzu F., Tamai S., 2010. Severe, short-term food restriction improves cardiac function following ischemia/reperfusion in perfused rat hearts. Heart Vessels 25, 417-425 